\title{
THE EFFECTIVENESS OF ACUPUNCTURE THERAPY IN REDUCING MELASMA IN AN INDONESIAN FEMALE POPULATION
}

\author{
Sri Yatmihatun'), Joko Tri Haryanto²), Risna Widowati3) \\ School of Health Polytechnics, Ministry of Health, Surakarta
}

\begin{abstract}
Background: Melasma is a common facial skin disorder seen in women.It is an acquired hypermelanosis of sun-exposed areas of the skin. Melasma is a chronic skin disorder that results in symmetrical, blotchy, and brownish facial pigmentation. Studies have shown thatmanual acupuncture (MA) is widely used alone or in combination with conventional treatment for melasma. This study aimed to determine the effectiveness of acupuncture therapy in reducing melasma in an Indonesian female population.

Subjects and Method: This was a randomized control trial study. The study was conducted at Kismoyo village, Ngemplak, Boyolali, Central Java, from June to September 2016. A sample of 30 women was selected for this study by simple random sampling and divided into two groups. The experimental group (15 women) received acupuncture therapy in melasma area and the control group (15 women) received sham acupuncture therapy. Acupuncture therapy is given 12 times every 2 weeks. The dependent variable was melasma (including grade of melasma darkness, hyperpigmentation, and melasma involvement). The independent variable was acupuncture therapy. The data of melasma were measured by melasma area severity index (MASI) and analyzed by MannWhitney test.

Results: Darkness area of melasma in the control group before acupuncture $($ mean $=16.43$ ) was higher than after treatment (mean=14.57), but statistically was not significant $(\mathrm{p}=0.502)$. Darkness area of melasma in treatment group before acupuncture $($ mean $=19.93)$ was higher than after treatment (mean= 11.07) and statistically significant $(\mathrm{p}=0.004)$. Hyperpigmentasi grade in control group before acupuncture $($ mean $=17.43)$ was higher than after treatment (mean= 13.57), but statistically was not significant $(\mathrm{p}=0.121)$. Hyperpigmentasi grade in treatment group before acupuncture (mean $=17.07$ ) was higher than after treatment $($ mean $=13.93)$, but statistically was not significant $(p=0.293)$. Melasma area in control group before acupuncture $($ mean $=16.27)$ was higher than after treatment $($ mean $=14.73)$ but statistically was not significant $(p=$ o.605). Melasma area in treatment group before acupuncture (mean $=20.43$ ) was higher than after treatment (mean $=10.57)$ and statistically significant $(p=0.001)$. Conclusion: Acupuncture is effective to reduce melasma, particularly in narrowing melasma area and reducing the darkness the affected area.
\end{abstract}

Keywords: melasma, acupuncture therapy

Correspondence:

Sri Yatmihatun. School of Health Polytechnics, Ministry of Health, Surakarta.

Mobile: 082300151915.

Mid-International Conference on Public Health, Best Western Premier Hotel, Solo, Indonesia, 18-19 April 2018 | 248 https://doi.org/10.26911/mid.icph.2018.05.10 